Hatcher, P. (2016). 'The politics of artisanal and small-scale mining in Mongolia', Third World Thematics 1(2): 184-201.

\title{
The Politics of Artisanal and Small Scale Mining in Mongolia
}

\author{
Pascale Hatcher
}

\begin{abstract}
Large-scale mining has become the cornerstone of Mongolia's development and poverty reduction narrative. Building on political economy insights, this paper explores the politics of artisanal and small-scale mining (ASM) in the competing context of the fast-pace development of large-scale mining in Mongolia. Questions are raised about the actors involved in promoting an 'investment-led model' which has privileged large-scale activities. Such context sheds light on the marginalisation of ASM activities in Mongolia, a sector which, despite being illegal until 2010, has continued to support 20 per cent of Mongolia's rural workforce.
\end{abstract}

Keywords: Extractive industry; Mongolia; small-scale artisanal mining; large-scale mining; neoliberalism 
You can't just stop artisanal mining. ASM will continue as long as poverty persists.

Mongolian government official, SAM conference ${ }^{1}$

\section{Introduction}

Mongolia's mining riches are astounding. It is estimated that the country rests on 6,000 deposits of 80 different minerals, notably coal, copper, gold, rare earth and iron ore. ${ }^{2}$ Spearheaded by international donors, Mongolia's mining regime has been highly successful in attracting foreign large-scale investments. In fact, the country is currently the construction site of what are expected to become two of the biggest mining development projects on Earth.

While in recent years, large-scale mining has become the cornerstone of Mongolia's development and poverty reduction narrative, there are growing tensions emerging from the severe socio-environmental impacts linked to the fast expansion of the sector. Crucially, if all eyes are currently on the large-scale sector, artisanal and small-scale mining (ASM), despite being illegal until 2010, continues to support 20 per cent of Mongolia's rural workforce and to account for nearly 10 per cent of revenues in the country.

Building on political economy insights, this paper explores the politics of ASM in the competing context of the fast-paced development of large-scale mining in Mongolia. ${ }^{3}$ Without in any way challenging the importance of acknowledging the particularities of the ASM-context in Mongolia, questions are here raised about the actors involved in promoting specific norms for and legitimising a neoliberal mining governance in the country. Such context sheds new light on the marginalisation of ASM activities in the country.

This paper is divided into four sections. In the first part, the paper presents the making of Mongolia's current mining regime, one that was highly successful in its objective of developing the industrial side of the sector under a particular 'investment-led' framework. The second section of this paper turns to ASM and analyses how the sector has developed alongside the country's large-scale sector. In turn, the paper discusses the process by which ASM has systematically been delegitimised and marginalised. In the last section of the paper, the current debate over the need to rethink the country's mining regime is analysed.

\section{The Making of Mongolia's Large-Scale Mining Sector}

While industrial mining activities were taking place across Mongolia during its 70 year long socialist era, Mongolia's large-scale mining sector has only recently begun to position itself as a global player. ${ }^{4}$ The foundations of the legal framework, which has propelled the country to its current status of one of the world's key mineral producers, were drawn in the early 1990s, amidst the country's rapid transition towards a market economy. Sponsored by a handful of multilateral organisations, the initial 'shock therapy' saw the liberalisation of prices, the removal of trade restrictions and the privatisation of state enterprises. ${ }^{5}$

Amidst this liberalisation, industrial mining was quickly identified as a key sector to generate the country's much needed revenues. In the mid-1990s, alongside most of the other resource-rich countries in the region, Mongolia embarked on a reform process that 
led to the adoption of a new mining legislation. ${ }^{6}$ The 1997 Mineral Law and later, the Foreign Investment Law (2002), were closely modelled on specific neoliberal norms and procedures, as advocated by international donors. ${ }^{7}$ These new laws sought to encourage foreign investments in the country's large-scale sector. The World Bank, which was a key player in assisting Mongolia in adopting a new mining regime (see Table 1), observed that:

The Bank has been supporting and nurturing the development of the regulatory framework for private sector led mining sector exploration and development for more than 10 years. During this time the focus of activities has been on establishing the legislative and fiscal regimes to apply to mining [...]. This work culminated in the passing of the 1997 Mineral Law and adoption of a reasonably competitive fiscal regime for the sector. ${ }^{8}$

Table 1. World Bank Extractive Related Project in Mongolia (1991-2012)**

*Over US\$1 million.

Additionally, in December 2015, the World Bank's International Financial Corporation and the Multilateral Investment Guarantee Agency committed US\$2,2 billion in loan and guarantee for the second phase of Oyu Tolgoi mine, the largest mine in the country. ${ }^{10}$

Beyond the single case of Mongolia, and as argued by Campbell in this contribution, the importance of the World Bank's overarching influence over the liberalisation and deregulation of mining sectors across poor indebted countries over the better part of the last three decades should not be understated. ${ }^{11}$ It is worth noting that the Extractive Industries Review (EIR), which was established in 2001 to independently evaluate the World Bank Group's (WBG) involvement in extractive industries, estimated that under the distinct leadership of the Bank no less than 100 countries had reformed their laws, policies, and institutions during the 1990s. ${ }^{12}$ The EIR further stressed that 'in line with WBG advice', this new legislation, which was designed to ensure the protection of capital and to promote investment, successfully brought many developing countries to experience an investment boom in their mining, oil, and gas sectors. ${ }^{13}$

Along the lines of the World Bank's recommendations, resource-rich countries adopted new legal frameworks prioritising a specific set of liberal norms and procedures geared to develop mining within a specific governance framework. Gagné-Ouellet summarises these norms: ${ }^{14}$

- Priority given to the private sector for mining development;

- Priority given to mining over other types of territorial use;

- Priority given to an exportable resource over other mineral resources;

- Priority given to the industrial sector over artisanal and small mines;

- Guarantees protecting mining rights. 
In line with such neoliberal norms, Mongolia's new mining regime sought to encourage foreign investors to participate in the exploration and large-scale development of Mongolia's mineral riches..$^{15}$ Unsurprisingly therefore, the 1997 Mining Law was regarded at the time as one of Asia's most attractive mining laws to foreign investors. ${ }^{16}$ The new Law prioritised the transparency, security, and transferability of property rights. Additionally, its low taxation and royalty burdens were particularly enticing to foreign investors. ${ }^{17}$ Crucially, and in accordance to the World Bank's guidelines for the sector, the role of the Mongolian state shifted from an 'ultimate land owner' to a manager/regulator of the sector..$^{18}$ As discussed by Campbell in this special issue, this 'stringent retrenchment of state' led to a new delineation between public and private spheres of authority, transferring what were previously considered public responsibilities to private actors. ${ }^{19}$ Albeit Campbell is here discussing the case of Africa, her observations resonate with the case of Mongolia. As argued later in this contribution, this process accounts for some of the failures by the Mongolian state to address some of today's most severe socioenvironmental impacts attached to the mining sector.

In contrast to the Law on Subsoil of 1989, the 1997 legislation, came to sever the links which were previously recognised between mining and the common and long-term public interests. ${ }^{20}$ The 1997 liberalisation marked the beginning of what was to quickly become a significant industrial 'mining boom' across the country. Urantsooj, President of the Mongolian Non-Governmental Organisation (NGO) Center for Human Rights and Development, observes that the fast pace of issuance of mining licences at the time, notably for the gold sector, has meant that 'almost the whole country was covered' ${ }^{21}$ Although revisions to the 1997 Mining Law in 2006 came to challenge some of its most liberal provisions, the country quickly became one of the world's key mineral producers. By 2012, Mongolia had reached the $7^{\text {th }}$ position in terms of world mineral and ore production, ${ }^{22}$ making it the centre of what the Financial Times referred to as an 'investment bonanza'. ${ }^{23}$

It is illustrative to note that the Gobi desert has been the construction site of what is projected to become the world's largest coal mine (Tavan Tolgoi), and the third-largest copper and gold mine (Oyu Tolgoi). Exceeding all expectations, Mongolia's economy was lifted by the mining wave and by 2011 , it had jumped to a staggering 17.5 per cent, making it the fastest growing economy in the world at the time - nearly twice as fast as China's. ${ }^{24}$ From contributing close to 13 per cent of the country's gross domestic product (GDP) in 2002 , mining accounted for 30 per cent of the country's GDP in 2012.25

Amidst demand from China and the commodity boom, the neoliberal norms drove the expansion of the sector and came to legitimise an 'investment-led' strategy for the fastpace development of the mining sector. Here, the large-scale sector found its legitimacy not only via the approbation of international donors and other organisations, ${ }^{26}$ but also with the socio-economic promises attached to the booming sector. These were closely linked to tax contribution and employment creation. However, and as discussed in the following section of this paper, this investment-led model further served to delegitimise ASM in the country, despite the sizeable contribution of the sector to poverty reduction.

\section{The Rise of the Ninjas}

While the 1997 Mining Law decidedly twined the fate of the country's economy to the industrial sector, it is telling to note that the Law completely ignored the very existence of ASM - the Law does not mention it once. However, and as indicative of the lack of legal 
status of ASM activities in many countries across the Global South, despite this de facto illegal status, the sector had already begun to flourish in Mongolia. ${ }^{27}$ It should be noted that in sharp contrast to many resource-rich countries, ASM in Mongolia is a very recent phenomenon. ${ }^{28}$ It emerged as a direct aftermath of the 'shock therapy' packages embraced by the country in the early 1990s, amidst the country's transition towards a market economy. The socio-economic impacts of the market reforms were sizeable - the GDP fell by approximately 20 per cent at that time. ${ }^{29}$ While unemployment had not been a problem before 1990, it had reached 8.7 per cent by 1994, and amidst the considerable waning of the country's social welfare system, poverty levels rose steeply. ${ }^{30}$

In addition to the country's bumpy turn towards the market economy, a series of extreme weather conditions to the sudden shift towards ASM. Between 1999 and 2002, Mongolia saw three consecutive extremely snowy and cold winters known as zuds, which seriously impacted livestock. ${ }^{31}$ Between 7 and 11 million head of cattle and other livestock perished in the aftermath of such $z u d s,{ }^{32}$ pushing rural communities into 'extreme poverty and economic desperation'. ${ }^{33}$ The majority of these herders moved to the capital and/or turned to ASM as an economic activity of last resort. ${ }^{34}$

It is however with the rise of gold prices that ASM established itself as a permanent activity in Mongolia - See Figure $1 .{ }^{35}$ Since the mid-2000s, the dwindling legal gold supplies and the spike in black market demand from neighbouring China have further contributed to heightened profits for ASM of gold in the country. ${ }^{36}$ 
Figure 1. Gold Prices (2000-2015) ${ }^{37}$

As observed by the Swiss Agency for Development Cooperation, ${ }^{38}$ with the ensuing gold rush, the unemployed urban population joined the ex-herders in becoming 'ninjas' - a term colloquially used to refer to small-scale and artisanal miners operating in the country. ${ }^{39}$

The overwhelming majority of ninjas - between 80 and 90 per cent - mine gold (both primary and placer), ${ }^{40}$ while the remainder mine for coal and fluorspar, as well as a small amount of semi-precious stones, tungsten and petrified wood.

With its harsh winter months, ASM is more of a seasonal occupation - although by no means exclusively. ${ }^{41}$ Men and women - the latter represent approximately a third of the workforce ${ }^{42}$ - involved in such activities include herders, farmers, students, factory workers, and even white-collar workers such as government officials. ${ }^{43}$ While on average, the sector pays much better than the Mongolian minimum wage, income from ASM remains particularly intermittent and volatile. ${ }^{44}$

The sudden development of the phenomenon, as well its scale, left the country's authorities in a state of shock and denial. ${ }^{45}$ Since its initial outbreaks in 1995-1996, ASM has spread to all but 3 of the country's 21 provinces. While until recently, authorities have resolutely tried to ignore the sector's very existence, as discussed in the following section, it is compelling to note that it has continued to expand alongside - and benefiting from the prioritisation of the industrial sector.

ASM in Mongolia remains controversial, a fact reflected in the attempts to estimate the number of the country's ninjas ${ }^{46}$ While some figures point towards 35,000 operating in the country, the actual figure is most probably closer to 100,000 people. ${ }^{47}$ Taking into account the fact that Mongolia's total population is three million, the sector's significance should not be understated. In fact, in rural areas, ASM is the largest generator of income after agriculture and accounts for 20 per cent of the total workforce. ${ }^{48}$ Moreover, these numbers do not account for the fact that each ninja is economically supporting three to four people. ${ }^{49}$ Today, according to the SDC, up to 400,000 people indirectly depend on the sector (13 per cent of the country)..$^{50}$

\section{ASM as a Nuisance}

Despite its substantial contribution to the local economy, ASM continues to be perceived as a nuisance. For national authorities, ASM was a temporary phenomenon ${ }^{51}$ and as such, most governmental initiatives have remained framed within the over-optimistic idea that if kept illegal, the sector would simply disappear. ${ }^{52}$

This widespread disapproval of ASM in public opinion has overwhelmingly sprung from the sector's environmental legacy, notably its impact on water and land, not withstanding the widespread use of mercury until it was made illegal in $2008 .{ }^{53}$ Corollary, relations between herders and ninjas have grown to be increasingly testing, with complaints linked to the deterioration of subsoil; livestock falling into the holes dug by miners, dried up rivers and springs; and water pollution. It is however important to stress that to a large extent, this environmental footprint derives from the fact that the sector had been kept illegal. Purevjav observes that ninjas have been struggling to implement environmentally 
friendly practices in relation to rehabilitation of degraded land due to their lack of access to knowledge, financial resources, and technological capacity. ${ }^{54}$

Tensions have also been noted between ninjas and the industrial sector. In a 2006 working paper, the World Bank observed that while initially large-scale operators tolerated the presence of informal miners if their activities were confined to the waste tailings, tacit understandings quickly broke down. ${ }^{55} \mathrm{SDC}$ further notes that:

The industrial mining sector has long seen ASGM [Artisanal small-scale gold mining] as an annoyance and depicted artisanal miners as villains, irresponsibly "destructing" mineral deposits and the environment, and opposing against modern mechanized mining. In areas where LSM [large-scale mining] works, ASGM is often either a traditional activity or artisanal miners had discovered the gold deposits. There are abundant cases - where these deposits turned out to be outcrops of a larger mineralization - where ASGM was subsequently displaced by LSM companies. Concession areas for LSM are often significantly larger than the area actually required for the mining operation, sometimes covering thousands of square kilometres. Such areas limit the possibilities of artisanal miners to do ASGM formally, and even on community land where ASGM had been a traditional activity, miners are often considered illegal and criminal invaders. ${ }^{56}$

In such an illegal environment, ninjas have been living on the edge of society, lacking security, knowledge, and skills to sustain their activity, as well as lacking a much-needed access to health care and social protection. This closely resonates with Hall, Hirsch and Murray Li's work on the concept of exclusion, ${ }^{57}$ which they see as structured by power relations, whether related to regulation, force, the market or legitimation. ${ }^{58}$

In the Mongolian case, and as argued in this contribution, one can clearly observe that regulations have indisputably favoured the industrial sector. In a de facto state of illegality, ASM workers have been the subject of use of force by both private and public security forces. The SDC report instances of 'police and military raids, direct confrontation, arrests and trials with - in some cases - rampant violations of human rights' ${ }^{59}$ In terms of structured power relations linked to the market, ninjas have a limited access to information and means to sell gold via legal channels. Here the 'ger shop', ${ }^{60}$ or the mill or truck owners have become the only accessible source of financial service for ninja miners, as well a convenient venue to sell the gold - mining sites are often far from financial institutions and Ulaanbaatar. Most middlemen then illegally sell the gold to Chinese or South Korean markets. ${ }^{61}$ In 2002, in order to curb these illegal channels, the Mongol Bank (the central bank) commenced purchasing gold at the world price from ASM directly and from gold buyers as private individuals. However, illegal channels have remained rampant.

Finally, and keeping with Hall, Hirsch and Murray Li's approach to the concept of exclusion, ${ }^{62}$ while large-scale mining activities in Mongolia have rapidly become 'legitimate', ASM has been systematically marginalised. In addition to its inability to mirror the scale of the economic promises of the industrial sector, ASM has lacked legitimacy in public opinion due to its historical environmental footprint across the country. Other factors contributing to the negative image of the sector are notably issues of child labour on ASM sites, tax evasion, rise in crime, and additional pressure on local administrations. ${ }^{63}$ High observes that for Mongolians living in the capital of Ulaanbaatar 'ninja mining is commonly regarded as an economic phenomenon driven by poverty and desperation' and that such activities are considered to be 'a blemish, if not an embarrassment' ${ }^{64}$ It is illustrative to note that throughout the $2000 \mathrm{~s}$, and to a certain extent still today, the terms 'ninjas', 'informal' and 'artisanal' all appear to mean 'illegal' mining. 
Unsurprisingly therefore, the government of Mongolia has long been cautious in proposing any legislation in regard to the legalisation of the sector 'for fear of being perceived as supporting a sector that remains so unpopular with the public' ${ }^{65}$ However, and as discussed in the following section, recent initiatives have began to emphasise the socioeconomic benefits of the sector and argue for the legalisation of ASM.

\section{The Legalisation of ASM}

In light of the importance played by ASM in rural economic development, employment creation, and poverty reduction, the Mongolian state, in collaboration with NGOs and international organisations, began to study regulatory options in the early $2000 \mathrm{~s} .{ }^{66}$

Here, it should be noted that this greater openness on the part of authorities to discuss ASM inscribed itself in important changes across the large-scale mining sector in the mid-2000s. In 2006, in a move that came to curb some of the most liberal provisions embedded in the 1997 Mining Law, the 1997 Mining Law was amended. The amendment sought to increase tax rates and state ownership over minerals, stipulating that in the cases of exploitation of minerals of 'strategic importance', the State would claim up to 34 per cent (Art. 5.5). ${ }^{67}$ While the World Bank was quick to condemn the adoption of the amendments as a 'pushback' by the state on private sector led development, ${ }^{68}$ the changes were significant as they conveyed the sense of unease for what was perceived as the overliberalisation of the large-scale sector and its correlated socio-economic and ecological impacts.

As further discussed by Campbell in this special issue, while large-scale mining activities can deliver economic growth, the 'investment-led model' has often failed to translate into economic benefits at local levels. ${ }^{69}$ Contrary to industrial mining, ASM: 'money first enters at the household level and begins to circulate from the bottom up, from the local to the regional and national economies.${ }^{70}$ Further to this, while promises of employment are key to the promotion of a neoliberal mining regime, it is interesting to note that according to the National Statistical Office of Mongolia, only 8,268 people were engaged in mining of metal ores in 2012, or a total of 19,217 people employed in the mining and quarrying sector and 61,661 people in the entire industrial division..$^{71}$ This is a far cry from the 100,000 ASM workers - 400,000 when taking into account the people being indirectly supported economically by ASM activities. This is not to downplay the quality and security attached to the much-coveted jobs in the large-scale sector but rather to emphasise the false premises attached to the overwhelming focus on an investment-led mining regime in terms of employment.

Further to this, and despite public opinion being focussed on environmental damage in the ASM sector, the investment-led model, which has privileged the industrial sector, had registered a serious environmental footprint. Mongolia's Mineral Resources Authority admits that since the beginning of the mining boom, 4,000 hectares of land have been adversely affected by mining - 500 mining sites affecting 56 towns in 15 different provinces $^{72}$ observes that:

Companies neglected environmental standards, and fared poorly on rehabilitation. Use of poor technology and obsolete equipment, the tendency of placer gold mines to be located in river basins, the use of river water for gold extraction and putting waste into rivers resulted in numerous reported cases of pollution and some rivers drying up. This, combined with the low regulatory enforcement capacity of the government, led to environmental problems 
which started affecting rural livestock herders as pastures and water resources became scarce. Many civil society groups, especially at the grassroots level, emerged in reaction to environmental concerns around mining, and ultimately some of these groups went beyond environmental issues in their quest to bring about more responsible mining practices.

This closely resonates with Campbell's observations in this special issue when the author observes that there exists a clear dichotomy introduced by norms imbedded in an investment-led model as it creates a distinction between the large and small scale sector which is somewhat removed from empirical reality. ${ }^{73}$

In Mongolia, amidst these overall changes in the country's mining sector, the role of ASM gradually began to be revisited. After all, despite operating in complete illegality, ASM was already supporting 15 per cent of the country's entire population - albeit indirectly - and the sector could sizably contribute to tax revenues.

Strikingly, the recent changes in the perception of the sector overwhelmingly derive from the decade-long efforts initiated by the Swiss Agency for Development Cooperation. ${ }^{74}$ The Agency's Sustainable Artisanal Mining Project (SAM), which began in 2005, played a fundamental role in introducing the concept of sustainable artisanal mining into public and policy dialogue. ${ }^{75}$

Initial regulations were tentatively introduced as early as $2001^{76}$ but the discussions over the official legislation faced insurmountable implementation problems over the better part of the following decade - mostly due to a lack of adequate consultation of the ninjas themselves. ${ }^{77}$

In December 2010, the formal approval of Resolution 308 marked the official legalisation of ASM. ${ }^{78}$ The legalisation of ASM in 2010 was hailed by the NGO the Mongolian Artisanal Miners' United Umbrella Association (MASM) as 'the first progressive step toward formalization of SSM' ${ }^{79}$ With the 2010 Law, the government was recognising the rights of ASM to work, mine land, and organise themselves into official partnerships. ${ }^{80}$ The legislation stipulates that miners must organise in 'unregistered partnerships' of no less than five members in order to engage in mining, which are regulated by local administrations and limited to areas not yet licensed for exploration and exploitation. ${ }^{81}$ In other words, the new legal provision gives artisanal miners the opportunity to scale up their activities into more formalised small-scale mining, to have a plot of land upon which to legally mine - provided that: i) deposits are of no commercial value for industrial exploitation; ii) deposits are already exploited waste deposits that have been abandoned and left as waste; and iii) the company and local authorities have mutually agreed to allow ASM work to take place.

With the newly found land rights, the legalisation of the sector gives ninjas the confidence to invest in technological improvements and workplace safety, resulting in 'better health, lesser accidents, higher productivity and secured livelihoods' ${ }^{82}$ It has also encouraged much needed training for the sector, as 90 per cent of the workers are 'nonprofessionals' ${ }^{83}$ Furthermore, access to social services has become a noticeable benefit of the legalisation of the sector. The Law stipulates that the Soum [district] governor is responsible for taking 'measures to provide health care and social welfare services to smallscale miners, and access to schools and kindergartens to their children'. In terms of environmental practices, the formalisation of the sector and the availability of mercuryfree technological alternatives have led to what the SDC refer to as 'excellent progress' ${ }^{84}$

A year after the enactment of the legalisation, 317 new partnerships had been established and 65.6 per cent of their members were enrolled in health insurance and 21.2 
per cent in social insurance. ${ }^{85}$ By December 2015, 7,325 people had formally registered in the sector, 30 per cent of who were women.$^{86} \mathrm{It}$ is to be noted that the annual income of these workers was a staggering 300 per cent above the country's minimum wage. ${ }^{87}$

However, despite such rise in the number of partnerships, the SDC estimates that 89 per cent of ASM activities still remain informal (as of 2015). ${ }^{88}$ According to the SDC, this is mostly due to ninjas' reluctance to pay taxes and a lack of access to viable land for the miners. ${ }^{89}$

However, in addition to a range of projects currently unfolding to further support the formalisation of the sector ${ }^{90}$, the Mineral Resource Authority of Mongolia's recent increase in allocation of ASM mining land will substantially expand the possibilities for formalisation in the sector. ${ }^{91}$ In fact, between 2013 and 2014, ASM gold sales rose by 115.2 per cent, validating what the SDC refers to as 'the immense economic potential of ASM when systems and mechanisms for formalization are in place to fully realize that potential' ${ }^{92}$ Furthermore, amidst the current economic downturn caused by the decrease of world prices and the decline of China's demand for minerals, the legalization process of ASM has allowed for the sector to make what the SDC refers to as "a tangible contribution" to the economy ${ }^{93}$ In 2015, the sector sold 6.7 tonnes of gold to the Bank of Mongolia almost half (46.3 per cent) of total gold-mining sales in the country. ${ }^{94}$ This represents USD 245 million in foreign exchange earnings and USD 6.1 million in royalties. ${ }^{95}$

\section{Conclusion}

Promoted by international donors such as the World Bank, the investment-led mining framework adopted by Mongolia has been highly efficient in attracting large-scale investments in the country. However, and as argued in this paper, while ASM has long been overshadowed by the socio-economic promises of this investment-led regime, there is a need to revisit the origins of the country's regulatory mining framework to understand the legitimisation process which has led to the very adoption of such framework.

This process sheds light on the existence of relations of power - relations in which external actors continue to play a central role - constraining changes in the neoliberal norms firmly embedded in the regime. In other words, these relations of power inform the conditions which would permit ASM to become an integral part of the discussion over the role of mining activities in the country's economy - and society a whole - rather than a marginalised sector. As such, in Mongolia and elsewhere, governments have begun to challenge some of the more liberal norms which have historically been promoted within an investment-led model. Here, the active role of governments in acknowledging the socioeconomic contribution of ASM is vital.

Finally, and as also noted by Campbell in her contribution to this special issue, there exists a clear need to link large and small scale mining in a manner which articulates rather than opposes activities within the sector as a whole and crucially, in a manner that prioritises the entire sector's contribution to the welfare of Mongolian people. ${ }^{96}$

\section{Bibliography}

ARM (Alliance for Responsible Mining), and SCS Global Services. "Artisanal Miners Now Can Prove They Are Legal." MINING.com, May 27, 2014. http://www.mining.com/web/artisanal-miners-now-can-prove-they-are-legal/. 
ARM, and SCS Global Services. "Ecological Gold from Mongolia: Artisanal Miners Obtain Fairmined Certification.” MINING.com, February 27, 2015.

http://www.mining.com/web/ecological-gold-mongolia-artisanal-miners-obtainfairmined-certification/.

Blunt, P. and G. Sainkhuu. "Serendipity and Stealth, Resistance and Retribution: Policy Development in the Mongolian Mining Sector." Progress in Development Studies 15, no. 4 (2015): 371-385.

Blunt, P. "Whose Resources are they anyway? Community Development Agreements in the Mongolian Mining Sector." Progress in Development Studies 14, no. 4 (2014): 383-399.

Burett, T., and C. Simons. "Waiting for Chinggis." New Internationalist, What has Development Done for Me?, 460 (March 2013): 35-37.

Campbell, B., ed. Mining in Africa. Regulation and Development. London, Ottawa and Uppsala: Pluto, IDRC and Nordica Africa Institute, 2009. http://www.idrc.ca/EN/Resources/Publications/openebooks/450-5/index.html.

Campbell, B., ed. Regulating Mining in Africa: For Whose Benefit? Uppsala: Nordiska Afrikainstitutet, 2004.

Campbell, B. "Revisiting artisanal and small scale mining sector: an invitation to renew research strategies and policy proposals", Third World Thematics, 2016.

Cane, I., A. Schleger, S. Ali, D. Kemp, N. McIntyre, A. Lechner, P. McKenna, B. Dalaibuyan, Nena Bulovic, and K. Lahiri-Dutt. Responsible Mining in Mongolia: Enhancing Positive Engagement. St-Lucia, QLD, Australia: Sustainable Minerals Institute, The University of Queensland, 2015. http://espace.library.uq.edu.au/view/UQ:362422.

Connors, J. "Mining Law and Policy Developments in Mongolia: Considerations for Foreign Investors.” Baker \& McKenzie International, February 10, 2011. http://www.bakermckenzie.com/files/Publication/6c2c6e96-263f-4ff1-82d8329718c366a7/Presentation/PublicationAttachment/24c777ae-04a0-4880-9cafd391b0ae7995/pn_tokyouraniummining_mongolia_feb10.pdf.

EITI (Extractive Industries Tranparency Initiative), and National Council of the Mongolia EITI. "Mongolia Extractive Industries Transparency Initiative (MEITI). Mongolia Eight EITI Reconciliation Report 2013.” Extractive Industries Transparency Initiative, December 15, 2014.

Ernst \& Young. "Mongolia. Mining and Tax Guide 2012/13." In The 2012 Worldwide Corporate Tax Guide, 783-91, 2012.

http://www.ey.com/Publication/vwLUAssets/Worldwide_corporate_tax_guide_20 12/\$FILE/WCTG_2012_Worldwide_Corporate_Tax_Guide.pdf.

Gagné-Ouellet, S. "Regulatory Framework Revision and Mining Regime Reform in Mali: Degrees of Rupture and Continuity." In Modes of Governance and Revenue Flows in African Mining, by B. Campbell. International Political Economy Series. Palgrave Macmillan, 2013.

Grayson, R., T. Delgertsoo, W. Murray, M. Tumenbayar, U. Tuul, D. Bayarbat, and C.-E. Baatar. "The People's Gold Rush in Mongolia. The Rise of the 'Ninja' Phenomenon." World Placer Journal 4, no. Special Issue (November 2004): 1112.

Gudynas, G. "The New Extractivism of the 21st Century: Ten Urgent Theses about Extractivism in Relation to Current South American Progressivism," Americas 
Program Report (Washington, DC: Center for International Policy, January 21, 2010).

Hall, D., P. Hirsch, and T.M. Li. Powers of Exclusion: Land Dilemmas in Southeast Asia. Honolulu: University of Hawai'i Press, 2011. http://www.uhpress.hawaii.edu/p7556-9780824836030.aspx.

Hatcher, P. Regimes of Risk: The World Bank and the Transformation of Mining in Asia. International Relations \& Development Collection. London: Palgrave Macmillan, 2014. http://www.palgraveconnect.com/doifinder/10.1057/9781137031327.

Heemskerk, M. "Gender Assessment of Small-Scale Mining in Mongolia." The Asia Foundation, October 2013.

High, M. "Gold Mining in Mongolia." In Encyclopaedia of the History of Science, Technology, and Medicine in Non-Western Cultures. Chapter 221, 2014.

High, M. "The Cultural Logics of Illegality: Living Outside the Law in the Mongolian Gold Mines." In Change in Democratic Mongolia: Social Relations, Health, Mobile Pastoralism, and Mining, by J. Dierkes, 249-70, Pre-copyedited version. Leiden: Brill Publishers, 2012.

http://www.research.ed.ac.uk/portal/files/12353426/Cultural_Logics_of_Illegality .pdf.

High, M. "Wealth and Envy in the Mongolian Gold Mines." Cambridge Anthropology 27, no. 3 (2008): 1-18.

International Fund for Agricultural Poverty (IFAD). "Rural Poverty in Mongolia." IFAD. Rural Poverty Portal. Accessed November 22, 2013. http://www.ruralpovertyportal.org/country/home/tags/mongolia.

Itty, P. "Responsible and Sustainable Artisanal Mining. A Golden Opportunity for Mongolia." Asia Brief. East Asia Division, March 2013, 4.

Jacobs, A. "Winter Leaves Mongolians a Harvest of Carcasses." The New York Times, May 19, 2010. http://www.nytimes.com/2010/05/20/world/asia/20mongolia.html.

Johnston, L. "Mongolia - Oyu Tolgoi Copper/Gold/Silver Mine Project Trip Report." Trip Report. Washington: USAID (United States Agency for International Development), June 2011. http://mongolia.usaid.gov/wpcontent/uploads/Mongolia-Oyu-Tolgoi-Trip-Report.pdf.

Khongorzul, D. "Mongolia and Central Asia in Transition." Ritsumeikan Journal of Asia Pacific Studies 26 (2009): 117-48.

Langfitt, F. "Mineral-Rich Mongolia Rapidly Becoming 'Mine-Golia."' Special Series Mongolia Booms. National Public Radio, May 23, 2012. http://www.npr.org/2012/05/21/152683549/mineral-rich-mongolia-rapidlybecoming-minegolia.

MASM (Mongolian Artisanal Miners' United Umbrella Association NGO). Small-Scale Mining and Human Rights Situation of Artisanal Small-Scale Miners in Mongolia. Geneva: Universal Periodic Review, 2014. https://uprdoc.ohchr.org/uprweb/downloadfile.aspx?filename=1661\&file=English Translation.

Mendoza, R.U., H. MacArthur, and A. Ong Lopez. "Extractive Industries, Children and Inclusive Growth: An Analysis of Mongolia, Papua New Guinea and TimorLeste." Working paper. UNICEF, January 2012. http://share.pdfonline.com/2c004f9c7d4340128a38c861e8da6724/UNICEF\%20E XTRACTIVES\%20PAPER\%20JAN2012.pdf. 
Mendoza, R.U., H. MacArthur, and A. Ong Lopez. "Extractive Industries, Human Development and Child Rights." Ulan Bator, October 20-22. http://www.undp.mn/mining/papers/MONGOLIA_CONFERENCE_mendoza.pdf

MIGA (Multilateral Investment Guarantee Agency). "MIGA: Supporting Mining Investments." MIGA Brief Mining. April 2013, World Bank Group edition. https://www.miga.org/documents/miningbrief.pdf.

"Mining Journal," 2014. http://en.mongolianminingjournal.com/home.shtml;jsessionid=E685EE3C91CB8 E9AB4D9BC809CA5D55F.

Naito, K., H. Myoi, J. Otto, D. Smith, and M. Kamitani. "Mineral Projects in Asian Countries - Geology, Regulation, Fiscal Regimes and the Environment." Resources Policy 24, no. 2 (June 1, 1998): 87-93. doi:http://dx.doi.org/10.1016/S0301-4207(98)00012-9.

Namkhaijantsan, D. "Learning-by-Doing: Civil Society Engagement in Mining in Mongolia." In Advancing the EITI in the Mining Sector. A Consulation with Stakeholders, edited by P. Mitchell, F. Paris, and C. Eads, 59-63. EITI (Extractive Industries Transparency Initiative), 2009. https://eiti.org/files/MINING\%20Compressed.pdf.

Packard, C., and O. Khurebold. "The Changing Legal Environment for Mining in Mongolia." Anderson \& Anderson LLP, 2010. zotero://attachment/220/.

Pilling, D. "Mongolia Open to Talks on Investment Law." Financial Times. May 29, 2012. http://www.ft.com/cms/s/0/3215c23a-a98e-11e1-9972-00144feabdc0.html.

Purevjav, B. "Human Rights and Mongolia’s Small-Scale Mining Sector." October 29, 2014.

http://asiafoundation.org/in-asia/2014/10/29/human-rights-and-mongolias-smallscale-mining-sector/.

SDC (Swiss Agency for Development and Cooperation) employee. Personal Communications, October 2013.

SDC (Swiss Agency for Development and Cooperation). "An update of ASM in Mongolia 2015.” Knowledge Hub desk, Sustainable Artisanal Mining Project, February 18, 2016. http://www.sam.mn/news_en.php?title=An-update-of-ASMin-Mongolia-2015

SDC. "Project Monitoring Sheet," 2013.

SDC. "Responsible and Sustainable Artisanal Mining - A Golden Opportunity for Mongolia." Asia Brief. East Asia Division, March 2013.

SDC. "SDC Experiences with Formalization and Responsible Environmental Practices in Artisanal and Small-Scale Gold Mining in Latin America and Asia (Mongolia)," 2011.

SDC. "The Small-Scale Mining Legal Framework Development Process." Sustainable Artisanal Mining Project, 2011. http://www.sam.mn/images/documents/erh_zui.pdf.

Stanway, D. “Mongolia's 'Ninja' Miners Help Sate China Lust for Gold.” Reuters, April 19, 2012, U.S. Edition edition. http://www.reuters.com/article/2012/04/19/usmongolia-gold-idUSBRE83I08V20120419. 
The Economist. "Before the Gold Rush." The Economist, February 16, 2013. http://www.economist.com/news/asia/21571874-mongolias-road-riches-pavedshareholders-tiffs-gold-rush.

Uitterdijk Appel, P.W. "Mongolia: From Zero to 100000 Small Scale Miners in Less Than 10 Years." Manilla, 2005. http://asmasiapacific.org/wpcontent/uploads/2014/07/Appel2005_Mongolia-From0To1000-1.pdf.

UNEP (United Nations Environment Programme). "Analysis of Formalization Approaches in the Artisanal and Small-Scale Gold Mining Sector Based on Experiences in Ecuador, Mongolia, Peru. Tanzania and Uganda. Mongolia Case Study," June 2012.

Urantsooj. Personal Communication, 2012.

Villegas, C. "Ninja Miners and Rural Change in Mongolia." Blog. Artisanal Small Scale Mining in and Around Protected Areas and Critical Ecosystems, August 26, 2013. http://www.asm-pace.org/blog/item/11-ninja-miners-and-rural-change-inmongolia.html.

Wacaster, S. "The Mineral Industry of Mongolia." 2012 Minerals Yearbook. Mongolia (Advance Release). U.S. Geological Survey Mineral Yearbook 2012. U.S. Department of Interior and U.S. Geological Survey, June 2014.

Werger, M., and M. Staalduinen. Eurasian Steppes. Ecological Problems and Livelihoods in a Changing World. Springer Science \& Business Media, 2012.

World Bank. "Mongolia. A Review of Environmental and Social Impacts in the Mining Sector." Discussion Papers. Environment and Social Development. East Asia and Pacific Region, May 2006.

World Bank. "Mongolia: Overview". World Bank website, 2015. http://www.worldbank.org/en/country/mongolia/overview.

World Bank. "Mongolia Poverty Assessment in a Transition Economy." Rural and Social Development Operations Division, China and Mongolia Department, East Asia and Pacific Regional Office, June 27, 1996. http://wwwwds.worldbank.org/servlet/WDSContentServer/WDSP/IB/1996/06/27/000009265 3961214164741/Rendered/PDF/multi0page.pdf.

World Bank. "Project Information Document: Concept Stage.” Mongolia Mining Sector Technical Assistance Project. Washington: Oil, Gas and Mining Policy Department, 2008.

World Bank. "Striking a Better Balance: Volume 1. The World Bank Group and Extractive Industries." Final Report. Extractive Industries Review (EIR). Jakarta and Washington: World Bank Group, December 2003. https://openknowledge.worldbank.org/handle/10986/17705.

World Gold Council. "Interactive Gold Price Chart | Gold Market Price," 2015. http://www.gold.org/investment/interactive-gold-price-chart.

Wu, J.C. "The Mineral Industry of Mongolia.” 1999 Minerals Yearbook Mongolia. U.S. Geological Survey Mineral Yearbook 1999. U.S. Department of Interior and U.S. Geological Survey, 1999.

${ }^{1}$ Villegas, "Ninja Miners and Rural." 
${ }^{2}$ In addition to these minerals, Mongolia is believed to have reserves of asbestos, bismuth, clays, copper, diamond, gemstones, graphite, gypsum, lead, limestone, magnesium, molybdenum, nickel, petroleum, phosphate, platinum-group metals, rare earths, salt, sand and gravel, silica, talc, tin, tungsten, uranium, zeolite, and zinc. Wu, "Mineral Industry of Mongolia," 15.1.

${ }^{3}$ The argument in this paper mostly builds on secondary data analysis. However, some of the material is corroborated by field visits held between 2012 and 2014 in Ulaanbaatar where government officials, Non-Governmental Organisations (NGOs) and international organisation officers, and mining company employees were interviewed.

${ }^{4}$ A definitions of large-scale mining activities is not provided in the country's mining code.

${ }^{5}$ These austerity packages were first adopted in 1991 and later, in 1994.

${ }^{6}$ For instance, Myanmar adopted a new mining law in 1994, Philippines in 1995, Vietnam and Kazakstan in 1996, China, Laos and Kyrgyzstan in 1997. On the topic, see Naito et al., "Mineral Projects.".

${ }^{7}$ The 1997 Minerals Law regulated relations with respect to exploration and mining of all types of mineral resources except water, petroleum and natural gas from June 1997 to August 2006.

${ }^{8}$ World Bank, "Project Information Document."

${ }^{9}$ Adapted from Hatcher, Regimes of Risk, 105.

${ }^{10}$ As part of a larger US $\$ 4,4$ billion loan package by multiple international lenders.

${ }^{11}$ Add Campbell reference to this special issue. Also see Campbell, Regulating Mining; Campbell, Mining in Africa; Hatcher, Regimes of Risk; Gudynas, "The New Extractivism."

${ }^{12}$ World Bank, "Striking a Better Balance," 10.

${ }^{13}$ Ibid., 3. Additionally, any evaluation of the weight of the Bank over mining should encompass the private arms of the Group: the IFC, which holds a mining portfolio of US\$500 million, and Multilateral Investment Guarantee Agency (MIGA), whose own portfolio currently stands at US\$240 million. See MIGA, "Supporting Mining Investments.". The IFC is a for-profit organisation which aims to support the growth of the private sector in developing countries. MIGA promotes foreign direct investment in developing countries. Its main activities are providing political risk insurance against certain non-commercial risks to investments.

${ }^{14}$ Gagné-Ouellet, "Regulatory Framework."

${ }^{15} \mathrm{Wu}$, "Mineral Industry of Mongolia," 15.1. (Our emphasis)

${ }^{16}$ Connors, "Mining Law and Policy," 12; High, "The Cultural Logics of Illegality," 6; Johnston, "Mongolia - Oyu Tolgoi," 2.

${ }^{17}$ Packard and Khurebold, "The Changing Legal Environment."

${ }^{18}$ High, "The Cultural Logics of Illegality," 6.

${ }^{19}$ Add Campbell reference to this special issue.

${ }^{20}$ High, "The Cultural Logics of Illegality," 6.

${ }^{21}$ Urantsooj, Personal Communication.

${ }^{22}$ Mendoza, MacArthur, and Ong Lopez, "Extractive Industries, Children," 4.

${ }^{23}$ Pilling, "Mongolia Open to Talks."

${ }^{24}$ Langfitt, "Mineral-Rich Mongolia." Although it was expected to further accelerate to a staggering 20 per cent in 2012 (Pilling, "Mongolia Open to Talks."), it fell quite short of expectations and decelerated to 12 per cent. This was blamed on falling commodity prices and a slowdown in China, as well as internal factors, notably the changes in the country's investment regime in 2013 and a dispute between the government of Mongolia and Oyu Tolgoi's investors, a dispute which was to last for the following two years (2013-15).

${ }^{25}$ Mendoza, MacArthur, and Ong Lopez, "Extractive Industries, Human Development," 4; Ernst \& Young, "Mongolia. Mining and Tax," 7.

${ }^{26}$ On the topic, see Blunt and Sainkhuu, "Serendipity and Stealth"; Blunt, "Whose Resources are they anyway?". 
${ }^{27}$ Artisanal and small-scale mining are activities difficult to define in the Mongolian context. While in this contribution we choose to pool them together, it is imperative to note that the term ASM encompasses a wide diversity in terms of legal frameworks, scale, demography and labour organisations. However, and as noted by Isabel Cane et al., ASM is commonly characterised by operations that 'typically exploit marginal or small deposits, lack capital and are labour intensive, have poor access to markets and support services, low standards of health and safety, and have a significant collective impact on the environment'. Cane et al., Responsible Mining in Mongolia, 69.

${ }^{28}$ While ASM did exist prior to the socialist period, Grayson et al. argue that it completely disappeared during the Soviet rule. Grayson et al., "The People's Gold Rush," 2.

${ }^{29}$ World Bank, "Mongolia Poverty Assessment," 28.

${ }^{30}$ Ibid., 28; Khongorzul, "Mongolia and Central Asia," 128. Before the transition, social inequalities were negligible and poverty was virtually inexistent in rural areas. IFAD, "Rural Poverty in Mongolia."

${ }^{31}$ It is estimated that in the aftermath of these $z u d s 15,000$ herders had lost all their animals), notwithstanding the fact that all the herders who might not have lost their entire stock were severely impacted. Werger and Staalduinen, Eurasian Steppes, 518.

${ }^{32}$ UNEP, "Analysis of Formalization Approaches," 4; SDC, "Responsible and Sustainable Artisanal Mining."

${ }^{33}$ UNEP, "Analysis of Formalization Approaches," 4.

${ }^{34}$ See Burett and Simons, "Waiting for Chinggis." Today, approximately 40 per cent of the population is engaged in traditional agriculture - primarily animal husbandry. While exact numbers are difficult to assess, there would be approximately 800,000 herders in Mongolia. Jacobs, "Winter Leaves Mongolian."

${ }^{35}$ High observes that during the socialist era, mining companies had a low gold recovery rate due to outdated technical equipment and as such, these sites have provided 'a relatively rich and readily accessible resource for artisanal and small-scale gold miners'. High, "Gold Mining in Mongolia," 1.

${ }^{36}$ Stanway, "Mongolia's 'Ninja' Miners."

${ }^{37}$ World Gold Council, "Interactive Gold Price Chart.".

${ }^{38}$ SDC, "Responsible and Sustainable Artisanal Mining," 2.

${ }^{39}$ See Grayson et al., "The People's Gold Rush," 2. The term Ninja originates from the fact that miners carry green panning bowls on their backs, which resemble the turtles' shells of the main characters in the movie Teenage Mutant Ninja Turtles, which came out in 1990. Today, the term is widely used by all stakeholders in the sector. See High, "The Cultural Logics of Illegality," 9.

${ }^{40}$ Villegas, "Ninja Miners and Rural." Placer means mineral concentration that has been separated from its first subsoil location as a result of erosion and mechanic processes and that are located as layers after reformation (see Art. 4.1.10 of Mongolia's 2006 Mining Law). In the case of gold, there is the 'left behind' by mining companies placer, and the placer in virgin deposits that is not in the reserves of mining companies. Grayson et al., "The People's Gold Rush," 7. ${ }^{41}$ Seasonal ninjas work on average from late April until late September.

${ }^{42}$ SDC, "Responsible and Sustainable Artisanal Mining," 1.

${ }^{43}$ EITI and National Council of the Mongolia EITI, "Mongolia Extractive Industries," 30. It is interesting to note that for High, ASM might not be entirely driven by poverty in the case of herders who undertake the activity. The author observed wealthy herders turning towards ASM as a means to increase a form of wealth which is 'less visible and measurable' than pastoral wealth, which 'is constantly visible and countable'. In so doing, herders avoid the social obligations which come attached to an increase in visible wealth. High, "Wealth and Envy," 9-10.

${ }^{44} \mathrm{In}$ a recent study of the sector, Isabel Cane et al. state that 64 per cent of the ninjas considered 
their income from artisanal mining to be 20 times higher than other sources of income. Cane et al., Responsible Mining in Mongolia, 73.

${ }^{45}$ Grayson et al., "The People's Gold Rush," 2.

${ }^{46}$ There are no definitions of ASM in the Mongolian Mining Law of 2006, nor in its 2006 revisions.

${ }^{47}$ SDC, "Responsible and Sustainable Artisanal Mining," 1.

${ }^{48}$ Heemskerk, "Gender Assessment of Small-Scale Mining," 7; SDC, "Responsible and Sustainable Artisanal Mining," 1; Uitterdijk Appel, "Mongolia: From Zero," 1.

${ }^{49}$ World Bank, "Project Information Document."

${ }^{50}$ SDC, "Responsible and Sustainable Artisanal Mining," 1.

${ }^{51}$ UNEP, "Analysis of Formalization Approaches," 6.

${ }^{52}$ SDC employee, Personal Communications.

${ }^{53}$ See High, "Gold Mining in Mongolia,"; Purevjav, "Human Rights."

${ }^{54}$ Purevjav, "Human Rights."

${ }^{55}$ World Bank, "Mongolia. A Review," 22; SDC, "SDC Experiences with Formalization," 16-17.

${ }^{56}$ SDC, "SDC Experiences with Formalization," 16-17.

${ }^{57}$ Hall, Hirsch, and Li, Powers of Exclusion.

${ }^{58}$ Hall, Hirsch and Li's (Ibid., 5.) further explain that 'regulation' is often but not exclusively associated with the state and legal instruments, sets of rules regarding access to land and conditions of use; 'force' excludes by violence or the threat of violence; 'the market' is a power of exclusion as it limits access though price and though the creation of incentives to lay more individualized claims to land; and 'legitimation' establishes the moral basis for exclusive claims, and indeed for entrenching regulation, the market and force as politically and socially acceptable bases for exclusion.

${ }^{59}$ SDC, "SDC Experiences with Formalization," 16-17.

${ }^{60} \mathrm{~A}$ 'ger' is a traditional tent in which many Mongolians live.

${ }^{61}$ World Bank, "Mongolia. A Review," 22-23.

${ }^{62}$ Hall, Hirsch, and Li, Powers of Exclusion.

${ }^{63}$ SDC, "The Small-Scale Mining," 7.

${ }^{64}$ High, "Wealth and Envy," 3. Also see High, "The Cultural Logics of Illegality."

${ }^{65}$ SDC, "The Small-Scale Mining," 22-23. A notable exception would be Soum (district)

governors, who, in light of their direct knowledge of the importance of the sector in terms of local livelihood, have traditionally been supportive of ASM (SDC employee, personal communications, October 2013).

${ }^{66}$ UNEP, "Analysis of Formalization Approaches," 6. Notably via projects by the Mining, Minerals and Sustainable Development project and a World Bank's Communities and Smallscale Mining initiative.

${ }^{67} \mathrm{Up}$ to 34 per cent where non-State funding sources are used to determine proven reserves or up to 50 per cent ownership where State funds are used (Art. 5.4).

${ }^{68}$ World Bank, "Project Information Document."

${ }^{69}$ Add Campbell reference to this special issue.

${ }^{70}$ Itty, "Responsible and Sustainable," 4.

${ }^{71}$ Cited in Wacaster, "The Mineral Industry of Mongolia," 17.2.

${ }^{72}$ Cited in Mendoza, MacArthur, and Ong Lopez, "Extractive Industries, Children," 18; Namkhaijantsan, "Learning-by-Doing," 60.

${ }^{73}$ Add Campbell reference to this special issue.

${ }^{74}$ Itty, "Responsible and Sustainable"; SDC employee, Personal Communications.

${ }^{75}$ Itty, "Responsible and Sustainable," 3. 
${ }^{76}$ The Interim Regulation No.33 on Gold Extraction by Non-Industrial Means (IR33), which had a 12 months life span, allowed for artisanal gold mining to take place on already licensed land. Soum (district) governments were given the authority to conclude agreements with mining license holders, allowing individual miners to rework tailings and waste rock. In turn, the mined gold was to be sold to the license holder. IR33 had a low participation rate. This was mainly due to the trying need to secure a tripartite agreement between the mining company, the ninjas and the local administration; and due as well to bureaucratic requirements. Grayson et al., "The People's Gold Rush," 67-68. Barely a year after its inception, IR33 was replaced by a slightly modified version of the regulation (IR53). While the latter was also short lived, some local officials continued to implement the regulation (Ibid., 60.)

${ }^{77}$ SDC, "The Small-Scale Mining," 8.

${ }^{78}$ The legal framework built on several consultations which were undertaken in 2009-2010 with more than 400 stakeholders, including members of parliament, central and local government officials, ASM representatives, NGOs and artisanal miners. UNEP, "Analysis of Formalization Approaches," 8.

${ }^{79}$ MASM, Small-Scale Mining.

${ }^{80}$ The new Law was met with the amendment of the Mineral Law, the Land Law and the Personal Income Tax Law.

${ }^{81}$ SDC, “The Small-Scale Mining," 22.

${ }^{82}$ Itty, "Responsible and Sustainable," 4.

${ }^{83}$ SDC employee, Personal Communications.

${ }^{84}$ SDC, "Responsible and Sustainable Artisanal Mining," 1.

${ }^{85}$ Itty, "Responsible and Sustainable," 3.

${ }^{86}$ SDC, "An update of ASM".

${ }^{87}$ Ibid.

${ }^{88}$ SDC 2016

${ }^{89}$ Cited in High, "Gold Mining in Mongolia," 2. Several issues with the 2010 regulation are being discussed by parliamentarians including: attempts to scale up artisanal mining into small-scale mining through miners partnerships and how many miners these should include; underground mining; whether basic deposits should be the object of ASM; the amount of land that should be allocated for ASM; the use of explosives; restrictions on equipment capacity; allocation of responsibility for occupational health and safety; environmental rehabilitation measures and costs and the use of mercury; depth of digging. SDC, "SDC Experiences with Formalization," 24. Furthermore, the new legislation has failed to tackle the practice whereby legal licence owners are subcontracting their plot to illegal miners, and in so doing, exposing the latter to serious human rights concerns, notably a weak safety environment

${ }^{90}$ ARM and SCS Global Services, "Artisanal Miners Now"; ARM and SCS Global Services, "Ecological Gold from Mongolia."

${ }^{91}$ Several issues with the 2010 regulation are being discussed by parliamentarians including: attempts to scale up artisanal mining into small-scale mining through miners partnerships and how many miners these should include; underground mining; whether basic deposits should be the object of ASM; the amount of land that should be allocated for ASM; the use of explosives; restrictions on equipment capacity; allocation of responsibility for occupational health and safety; environmental rehabilitation measures and costs and the use of mercury; depth of digging. SDC, "SDC Experiences with Formalization," 24.

Furthermore, the new legislation has failed to tackle the practice whereby legal licence owners are subcontracting their plot to illegal miners, and in so doing, exposing the latter to serious human rights concerns, notably a weak safety environment.

92 Ibid. 
${ }^{93}$ By 2012, the sector was contributing between US\$9 and 10 million to the local economy, and 821 miners were contributing 82 million MNT in income tax. SDC, "Project Monitoring Sheet," 1. Also see SDC, "An update of ASM".

94 SDC, "An update of ASM".

${ }^{95}$ Ibid.

${ }^{96}$ Add Campbell reference to this special issue. 